\title{
Thrips tabaci (Lind.) (Thysanoptera, Thripidae), another vector for tomato spotted wilt virus in Finland
}

\author{
ANNE LEMMETTY and ISA LINDQVIST \\ Lemmetry, A. \& Lindevist, I. 1993. Thrips tabaci (Lind.) (Thysanoptera, Thripidae), \\ another vector for tomato spotted wilt virus in Finland. Agric. Sci. Finl. 2: 189-194. \\ (Agric. Res. Centre of Finland, Inst. PI. Protect., FIN-31600 Jokioinen, Finland.)

\begin{abstract}
Populations of Thrips tabaci transmitted the isolate of tomato spotted wilt virus (TSWV) from infected china asters to healthy china asters in laboratory experiments.

Great variation was observed among absorbance values between thrips infested china asters. The highest absorbance values were obtained from stems of thrips inoculated plants.

According to our results, $T$. tabaci seems to be a noteworthy TSWV vector in Finland, where it is the only naturally occurring TSWV vector species. It is also one of the main pests on greenhouse crops in addition to Frankliniella occidentalis, the
\end{abstract} \\ primary vector of TSWV.
}

Key words: TSWV, china aster, thrips, transmission, detection, ELISA

\section{Introduction}

Tomato spotted wilt virus (TSWV), a member of the tospovirus group, is vectored by seven thrips species; Frankliniella occidentalis (Perg.), F. schultzei (Trybom), F. fusca (Hinds), Thrips tabaci (Lind.), T. setosus (Moulton), T. palmi (Karny) and Scirtothrips dorsalis (Hood) (GERMAN et al. 1992). The specificity between TSWV and these thrips species among 5000 known thrips species (ZUR STRASSEN 1960) is not yet understood. According to SAKIMURA (1962), the thrips must acquire TSWV as nymphs in order to transmit the virus. $F$. occidentalis is considered to be the primary vector of TSWV in many countries (ALLEN and BROADBENT 1986, CHO et al. 1987).

Only one of the above mentioned species, $T$. tabaci, is known to occur naturally in Finland, where it is one of the main pests of greenhouse vegetables and ornamentals. In recent years, also $F$. occidentalis has become a serious and rather common pest in many Finnish greenhouses.

Although T. tabaci has been reported to be a vector of TSWV (BEST 1968), some studies indicate that not all insect populations or virus isolates are equally acquired (MAU et al. 1991) or transmitted (PALIWAL 1974, 1976) by this species.

In Finland, TSWV has been isolated from tomato and chrysanthemum in 1989 (LEMMETTY 1991) and from cineraria in 1992. In both cases there were significant populations of $F$. occidentalis and $T$. tabaci in the greenhouses where the virus was isolated.

The object of this study was to find out whether TSWV can be vectored by $T$. tabaci alone.

\section{Material and methods}

The virus isolate used in this study was obtained from naturally infected cineraria (Senecio $x$ 


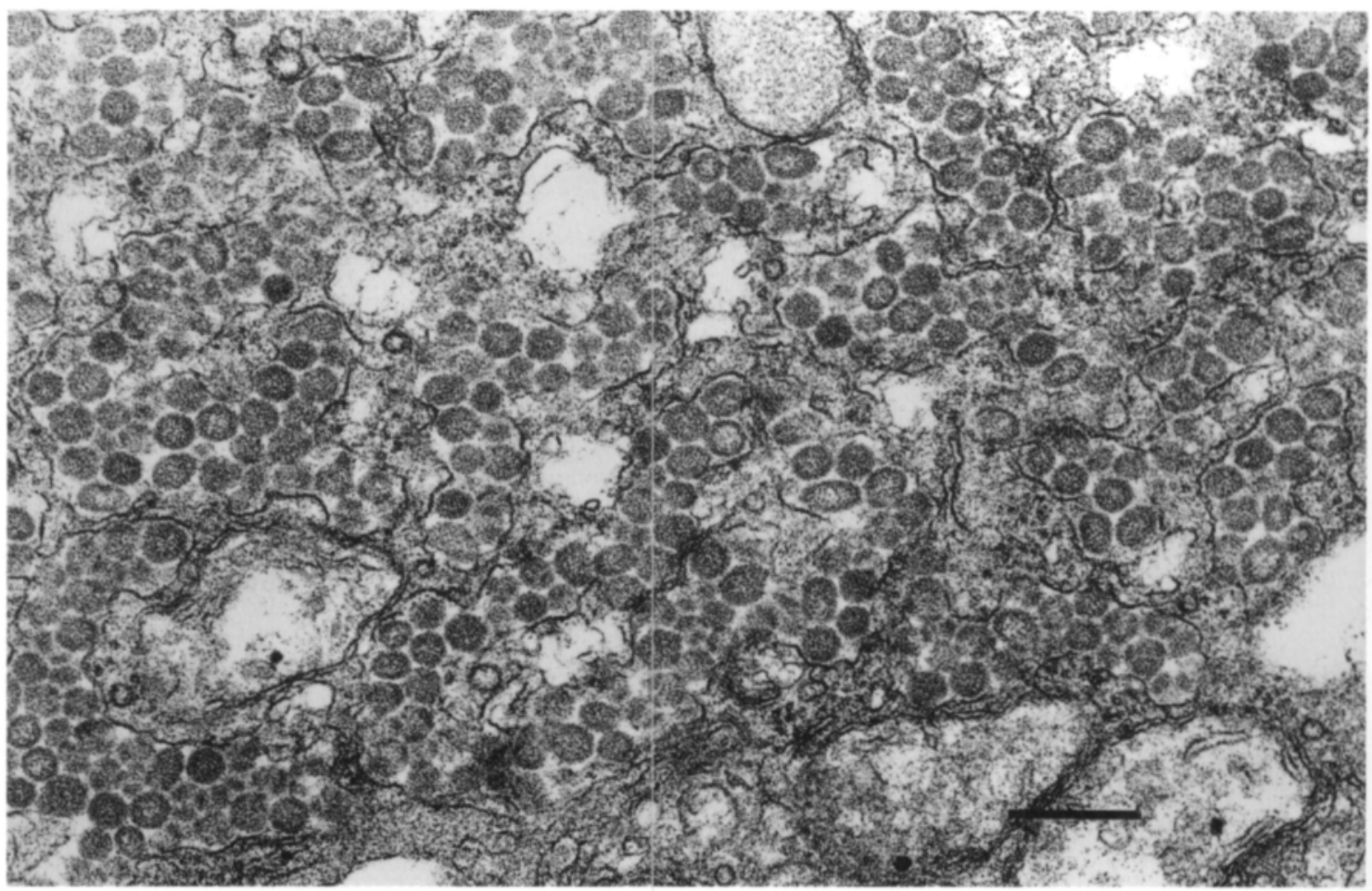

Fig. 1. Electron micrograph of spherical particles of TSWV on a thin section of Senecio $\mathrm{x}$ hybridus leaf tissue.

Bar represents $250 \mathrm{~nm}$. (Photo Anne Lemmetty).

hybridus) by sap transmission. Identification of TSWV was based on symptoms on host plants, enzyme-linked immunosorbent assay (ELISA) and electron microscopy (Fig. 1).

To test thrips transmission, young and healthy china asters (Callistephus chinensis Nees.) cv. Remo original, planted in $10 \mathrm{~cm}$ plastic pots, were sap inoculated (0.05 M phosphate buffer, $\mathrm{pH} 7.0)$ with TSWV isolate. Inoculated asters, which showed necrotic local lesions and a yellow-green systemic mosaic, were tested by ELISA two weeks after inoculation. Asters of which sap gave absorbance values ( $\mathrm{A}_{405 \mathrm{~nm}}$ ) between 1 and 2 were chosen for the experiments.

Three experiments were conducted during May to August 1992. Metal framed hard plastic cages, $60 \times 60 \mathrm{~cm}$ in size, were used. The top of the cage was covered with a cloth, and on one side there was a narrow door. The cages were standing on a metal plate with a $5 \mathrm{~cm}$ layer of peat on each to allow pupation of thrips. Approximately 50 thrips were transferred one by one on each of the six TSWV inoculated asters, using a fine-tipped moistened brush. Mainly second instar larvae, but also some adults, were transferred on two or three leaves above the inoculated leaves. The plants were spaced apart from each other in the cage and the larvae were allowed free access to feed on leaf surfaces for acquisition of the virus. The thrips completed their development and approximately three weeks later, after adult emergence, the TSWV inoculated asters were cut and left on one side of the cage for two to three days. Six young and healthy asters, cv. Carmen, 10-15 cm high, with six to ten leaves on each, were placed on the other side of the cage.

Two of the cages ( 1 and 2 ) were placed on a table in the laboratory and the third cage (3) into a growing chamber. The plants and thrips were maintained at $24 \pm 1^{\circ} \mathrm{C}$ with a $16 \mathrm{~h}$ light and $8 \mathrm{~h}$ dark cycle. All 
the thrips used in the experiments were laboratory reared and originated from colonies maintained on healthy china asters.

The development of feeding scars was observed and thrips populations were monitored. Two weeks after healthy asters had been placed into the cages, additional healthy plants were placed in the cages to minimize the feeding damage.

ELISA tests were done on leaf samples from healthy asters approximately three weeks after they had been exposed to $T$. tabaci. Two to three leaves, depending on the size and feeding damage, were removed from each plant for ELISA. Both old and young leaves were sampled. All plants were assayed for TSWV infection twice after the healthy asters had been placed in the cages.

Samples for the second ELISA were taken from leaves of the six asters in cage 1, from stems of the six asters in cage 2 and from leaves and stems of the six asters in cage 3 .

A commercial diagnostic kit was purchased from Loewe Biochemica GmbH, Germany. The antiserum used in all ELISA tests was against the nucleocapsid protein of the strain CNPH (de AVILA et al. 1990). All samples were tested by direct double antibody ELISA according to the instructions of the kit, using a 1 to 50 dilution of pressed sap in sample buffer.

Absorbance values (A405 nm) were measured after one hour of substrate incubation at room temperature. Each value of one plant was the mean of four wells. A sample was considered TSWV positive if the absorbance value was greater than three times the mean value of a healthy control. The healthy control asters originated from the same lot as those exposed to TSWV.

\section{Results}

Populations of T. tabaci transmitted the TSWV isolate from infected china asters to healthy china asters. The results of the three experiments repeated in successive weeks were consistent (Fig. 2).

After pupation, there were numerous adult $T$. tabaci in each cage. Severe feeding damage, browning and scorching of foliage, was rapidly

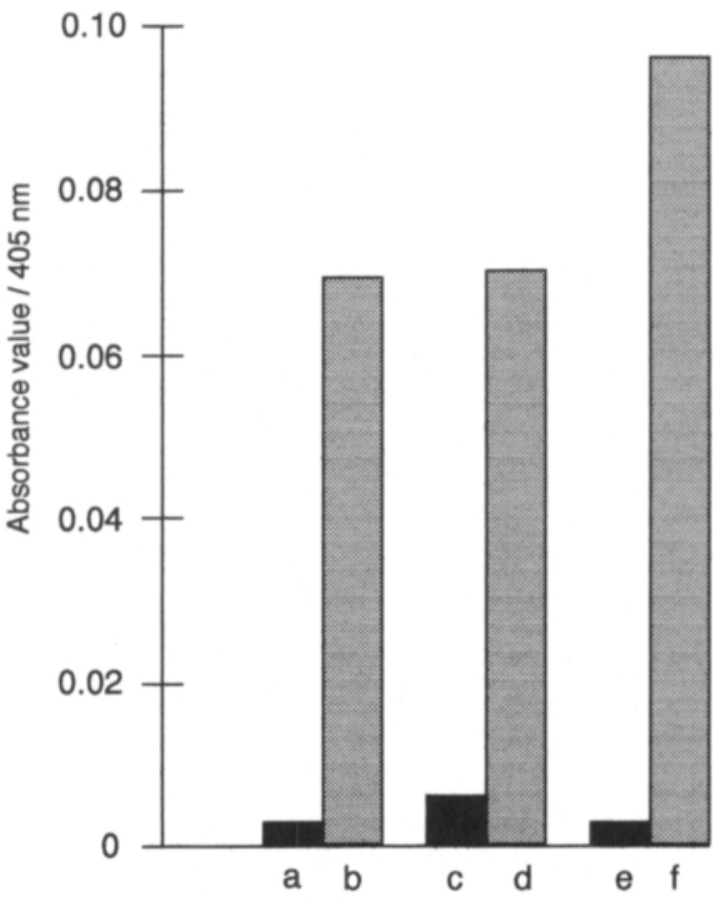

\begin{tabular}{|ll|}
\hline a & healthy aster \\
b & cage 1, plants exposed to virus \\
c & healthy aster \\
d & cage 2, plants exposed to virus \\
e & healthy aster \\
f & cage 3, plants exposed to virus \\
\hline
\end{tabular}

Fig. 2. TSWV absorbance values of china asters after exposure to TSWV transmission by T. tabaci for 25 days (cage 1) and 24 days (cages 2 and 3). Mean absorbance values of leaves of six china asters (cages 1 and 3) and four china asters (cage 2)

obvious. Indeed, two china asters (cage 2) became so desiccated that only their stem tissue could be tested.

TSWV was readily detected by ELISA after a three weeks' exposure period of the healthy plants to $T$. tabaci. The first ELISA test yielded generally low absorbance values. However, leaf samples of one plant gave an exceptionally high absorbance value compared to the others (Fig. 3).

In general, the longer the exposure time between transferring the healthy plants into the cage and 


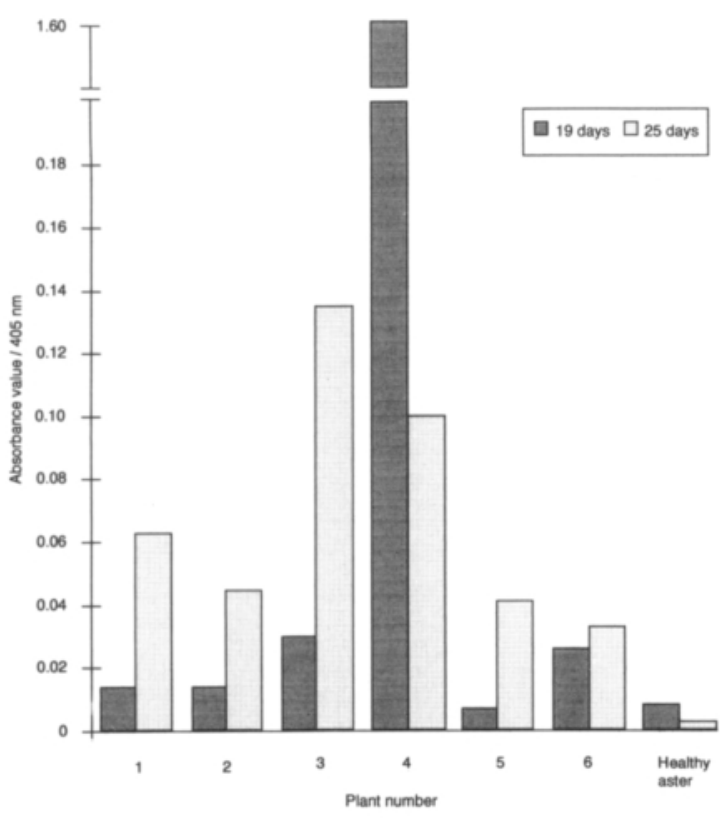

Fig. 3. TSWV absorbance values of six china asters in cage 1. Values were recorded after plants had been exposed to TSWV transmission by $T$. tabaci for 19 and 25 days.

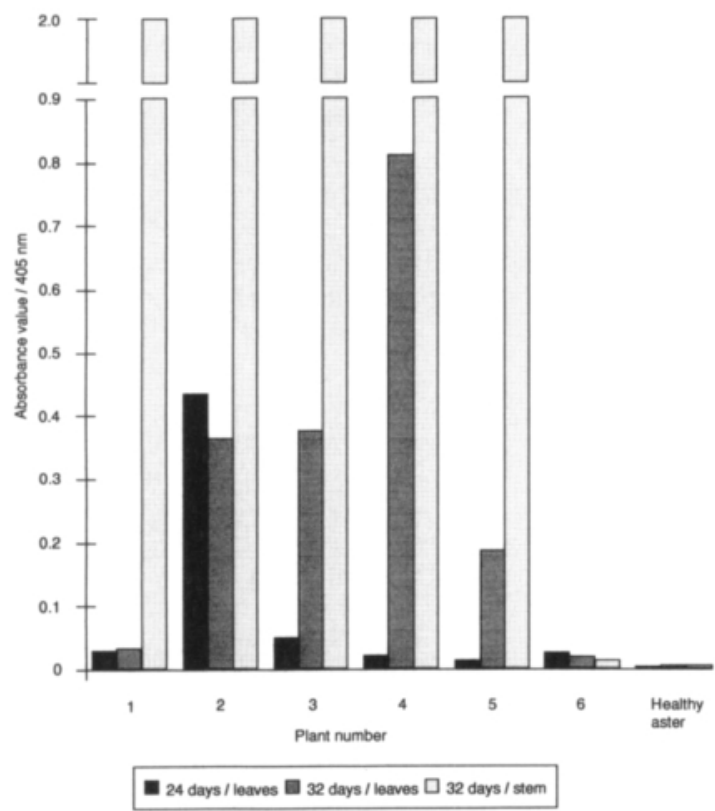

Fig. 4. TSWV absorbance values of six china aster leaves and stems in cage 3 . Values were recorded after plants had been exposed to TSWV transmission by T. tabaci for 24 and 32 . days. testing the plants, the higher the absorbance values (Figs. 3 and 4). The first maximum absorbance value $(>2)$ was obtained from the stem of a china aster in cage 2 when the plants had been exposed to TSWV for 24 days. Maximum absorbance values were also measured from the stems of five china asters in cage 3 after the plants had been exposed to TSWV transmission by T. tabaci for 32 days (Fig. 4). The absorbance values of healthy controls in six ELISA tests ranged from 0.003 to 0.008 .

TSWV was detected by ELISA in extracts from leaves or stems of china asters. However, as shown in Fig. 4, the stem tissue gave higher absorbance values.

\section{Discussion}

Our laboratory experiments demonsrated that $T$. tabaci is capable of obtaining and transmitting TSWV as also reported by SAKIMURA (1963), even though PALIWAL (1976) and REDDY et al. (1983) could not confirm Sakimura's report. Some assumptions have been presented to elucidate the nontransmissibility of TSWV by T. tabaci. CHO et al. (1991) found out that TSWV was not transstadially passed from larvae to adults in T. tabaci although that happened in F. occidentalis, the primary vector of TSWV. ZAWIRSKA (1976) explained that failure to spread TSWV by $T$. tabaci correlated with the absence of males in Polish T. tabaci populations.

Two factors may have served as preconditions for successful transmission of TSWV by T. tabaci in our experiment. Firstly, the TSWV isolate involved was detected with the antiserum raised against the CNPH strain. It was very likely that our TSWV isolate belonged to a common serogroup because some exceptional strains seem to require special thrips species for transmission (GERMAN et al. 1992). Secondly, the TSWV isolate found in cineraria was only once transferred by sap inoculation from cineraria to asters. It has been observed that TSWV can lose its vector transmissibility after prolonged culture by sap transmission (BEST 1968). IE (1982) also suggested that it is unlikely that the 
defective form of TSWV would be transmitted by thrips.

Undoubtedly there are differences in transmission efficiency of TSWV isolates by different species of thrips as demonstrated by PALIWAL (1976). In our trial the density of $T$. tabaci was high; even if the transmission efficiency could have been low, the thrips transmitted TSWV. The number of larval thrips was unnecessarily high as our assumption that the larvae would suffer from being transferred with a brush turned out to be incorrect.

We found asters a very suitable source plant for T. tabaci-TSWV transmission assays. Firstly, $T$. tabaci fed readily on asters and, secondly, asters provided systemic infection of TSWV with relatively high virus titer for a prolonged period. In some host plants it is typical of TSWV that the virus titer is maintained high for only one to two days before a dramatic decrease (BEST 1968).

The stage of larval thrips may affect the trans- mission efficiency of TSWV. In our trial, most of the thrips were transferred on the infected asters as second instars. SAKIMURA (1961) found that the feeding activity of $T$. tabaci larvae on Emilia leaves increased during the second instar stage.

Our results showed great variation in absorbance values of the asters inoculated by thrips. This might be due to the fact that TSWV is unevenly distributed in host plants. It was interesting to find out that the TSWV concentration was highest in stems of asters. Also ALLEN et al. (1990) detected TSWV in stems of chrysanthemum by ELISA.

There are still open questions concerning the transmissibility of TSWV by T. tabaci, but this study provided information that $T$. tabaci populations in greenhouses can be a link between TSWV infected and healthy plants. So far, the spread of TSWV infected plant material has been restricted in Finland and no epidemic has yet become prevalent.

\section{References}

Allen, W. R. \& Broadbent, A. B. 1986. Transmission of tomato spotted wilt virus in Ontario greenhouses by the westem flower thrips Frankliniella occidentalis (Pergande). Can. J. Pl. Path. 8: 33-38.

-, Matteoni, J. A. \& Broadbent, A. B. 1990. Susceptibility of cultivars of florist's chrysanthemum to tomato spotted wilt virus. Can. J. PI. Path. 12: 417-423.

Avil.a, A. C. de, Huguenot, C., Resende, R. O., Kitajima, E. W., Goldbach, R. W. \& Peters, D. 1990. Serological differentiation of 20 isolates of tomato spotted wilt virus. J. Gen. Virol. 71: 2801-2807.

BEst, R. J. 1968. Tomato spotted wilt virus. In: Smith, K. M. \& Lauffer, M. A. (eds.). Adv. Virus Res. 13: 65-146.

Cho, J. J., Mrtchell, W. C., Mau, R. F. L \& Sakimura, K. 1987. Epidemiology of tomato spotted wilt virus disease on crisphead lettuce in Hawaii. Pl. Dis. 71: 505-508.

-, Mau, R. F. L., Ullman, D. E. \& Custer, D. M. 1991. Detection of the tomato spotted wilt virus (TSWV) within thrips. In: Hsu, H. T. \& Lawson, R. H. (eds.). Virus-thrips-plant interactions of tomato spotted wilt virus . Proc. USDA workshop. ARS-87. Beltsville. p. 144-152.

German, T. L., Ullman, D. E. \& Moyer, J. W. 1992. Tospoviruses: diagnosis, molecular biology, phylogeny, and vector relationships. Ann. Rev. Phytopath. 30: 315348.

IE, T. S. 1982. A sap-transmissible defective form of tomato spotted wilt virus. J. Gen. Virology. 59: 387-391.

Lemmetry, A. 1991. First reported occurrence of tomato spotted wilt virus in greenhouse crops in Finland. Växtskyddsnotiser 55: 7-9.

Mau, R. F. L., Bautista, R., Cho, J. J., Ullman, D. E., Gusukuma-Minuto, L. \& Custer, D. 1991. Factors affecting the epidemiology of TSWV in field crops: comparative virus acquisition efficiency of vectors and suitability of alternate hosts to Frankliniella occidentalis (Pergande). In: Hsu, H. T. \& Lawson, R. H. (eds.). Virusthrips-plant interactions of tomato spotted wilt virus. Proc. USDA workshop. ARS-87. Beltsville. p. 21-27.

Paliwal, Y.C. 1974. Some properties and thrip transmission of tomato spotted wilt virus in Canada. Can. J. Bot. 52: 1177-1182.

-1976 . Some characteristics of the thrip vector relationship of tomato spotted wilt virus in Canada. Can. J. Bot. 54: $402-405$.

Reddy, D. V. R., Amin, P. W., Mc Donald, D. \& Ghanekar, A. M. 1983. Epidemiology and control of groundnut bud necrosis and other diseases of legume crops in India caused by TSWV. In: Plumb, R. T. \& Thresh, J. M. (eds.). Plant virus epidemiology. Oxford. p. 93-102.

SAKIMURA, K. 1961. Techniques for handling thrips in transmission experiments with the tomato spotted wilt virus. Pl. Dis. Rep. 45: 766-771.

- 1962. The present status of thrips-borne viruses. In: Ma- 
ramorosch, K. (ed.). Biological transmission of disease agents. New York. p. 33-40.

- 1963. Frankliniella fusca, an additional vector for the tomato spotted wilt virus, with notes on Thrips tabaci, another vector. Phytopath. 53: 412-415.

ZAWIRSKA, I. 1976. Untersuchungen über zwei biologische typen von Thrips tabaci Lind. (Thysanoptera, Thripidae) in der VR Polen. Arch. Phytopath. Pfl.schutz. Berlin. 12: 411-422.

Zur Strassen, R. 1960. Cataloque of the known species of
South African Thysanoptera. J. Ent. Soc. S. Afr. 23: 321-367.

Manuscript received February 1993

Anne Lemmetty

Isa Lindqvist

Agricultural Research Centre of Finland

Institute of Plant Protection

FIN-31600 Jokioinen, Finland

\title{
SELOSTUS
}

\section{Tupakkaripsiäinen, Thrips tabaci (Lind.), tomaatin pronssilaikkuviruksen (TSWV) toinen vektori Suomessa}

\author{
ANNE LEMMETTY ja ISA LINDQVIST
}

Maatalouden tutkimuskeskus

Tomaatin pronssilaikkuvirus on aiheuttanut suuria vahinkoja eri puolilla maailmaa vihannes- ja koristekasviviljelmillä. Suomessa virus löydettiin ensimmäisen kerran vuonna 1989 tomaatista ja krysanteemista sekä vuonna 1992 sineraariasta. Virusta levittävät aikuiset ripsiäiset, jotka ovat toukkavaiheessa syöneet viroottista kasvia.

Tehokkaimpana viruksen levittäjänä pidetään kalifornianripsiäistä (Frankliniella occidentalis), mutta kuuden muun ripsiäislajin on myös todettu siirtävän virusta. Tupakkaripsiäisen siirrostuskyvystä on kuitenkin ristiriitaisia tietoja.

Laboratoriokokeen tarkoituksena oli selvittää, siirtääkö tupakkaripsiäinen TSWV:tä. Kokeessa käytetty ripsiäispopu- laatio kasvatettiin terveissä astereissa laboratorio-olosuhteissa. Tutkittu virusisolaatti oli eristetty sineraariasta. Häkkikokeessa tupakkaripsiäistoukat siirrettiin TSWV:n infektoimille kasveille, joita ne saivat vapaasti syödä. Kun koteloituneista toukista alkoi kehittyä aikuisia, häkkeihin siirrettiin terveitä astereita syöttikasveiksi. Kasvien viroottisuus testattiin ELISA-menetelmää käyttäen.

Kokeessa todettiin tupakkaripsiäisen siirtäneen TSWV:n infektoituneista kasveista terveisiin kasveihin. Tupakkaripsiäinen on ainoa maassamme luontaisesti esiintyvä TSWV:n vektorilaji. Sen yleisyyden huomioon ottaen se on kokeen perusteella huomionarvoinen TSWV:n siirtäjä Suomessa. 